\title{
100-year Anniversary of the Birth of V.J. Sukselainen, Founder of Väestöliitto
}

\author{
JOUKO HULKKO, Master of Laws \\ Managing Director of Väestöliitto, 1968-2002
}

Vieno Johannes Sukselainen was born in Paimio on 12 October 1906. His mother was a single woman who worked as a seamstress. Sukselainen matriculated from high school in 1927 and earned his master's degree in 1931. Sukselainen's doctoral dissertation, "Co-operatives as a business model", was approved in 1939. Sukselainen traveled to various countries during the 1930s to conduct research for his dissertation, including Germany, Switzerland, France and Sweden. He was actively involved in student politics and later in the 1930s also got involved in the activities of the Agrarian League. Although neither farmer nor Member of Parliament, Sukselainen was elected chairman of the Agrarian League in 1945. His chairmanship lasted nearly two decades, until 1964, and his contributions were mainly in the area of political economy and social policy.

Sukselainen was a member of parliament almost without interruption from 1948 to 1978, and was Speaker in 1956-58, 1968-69 and 1972-75. Sukselainen occupied the post of Minister of Finance in 1950-51 and 1954, Minister of the Interior in 1951-53, and Prime Minister in 1957 and 1959-61. He also served as a university lecturer and professor of political economy throughout the 1940s and 50s, director of the Social Insurance Institution of Finland in 1954-71 and Chancellor of the University of Tampere in 1969-78. A founder of the Family Federation, Sukselainen was also its first chairman from 1941 until 1971.

Sukselainen and Elma Bondén, M.A., married on 6 July 1938 and had four children. V.J. Sukselainen died in 1995.

During the 1930s, experts throughout Europe, including Finland, noted the declining birth rates with great concern. On 17 October 1934, Gunnar Modeen, senior actuary of the Central Statistical Office (today's Statistics Finland), delivered a presentation at the Finnish Economic Association on the future of population development in Finland and its economic consequences. He suggested that Finland's population would 


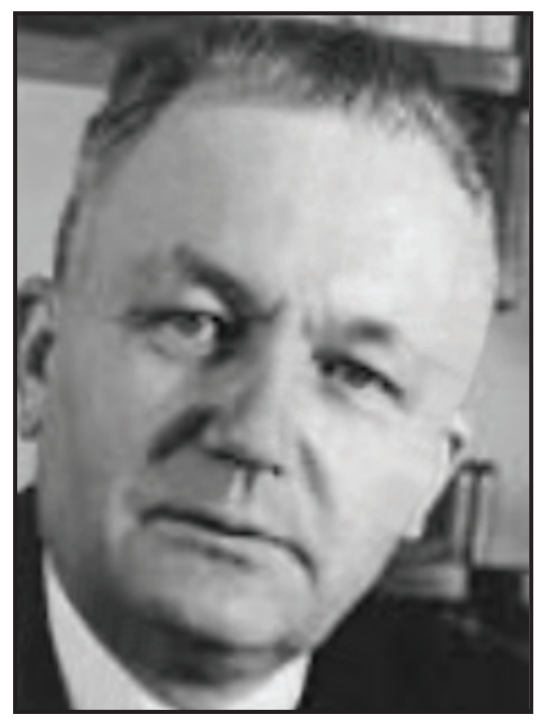

\section{V.J. Sukselainen (1906-1995)}

begin to decline during the first half of the 1970s and that it would never surpass the four-million mark. The lecture, which provoked wide-spread debate on the population question in the media and various organizations, laid the groundwork for discussing population policy in our country. In 1937, the Ministry for Social Affairs and Health established a committee to explore the population question, and that same year, legislation on maternity benefits was enacted. However, although parliament was now debating population issues, an official population policy had yet to be developed. On the day of the Winter War peace agreement, as he addressed the nation about the harsh conditions for peace, Minister for Foreign Affairs Väinö Tanner said: "Our only failure was that there were too few of us". The Minister's words took root in the minds of his Finnish audience, helping to pave the way for the population policies of the future.

V.J. Sukselainen was on the board of the Association of Finnish Culture and Identity (Suomalaisuuden liitto), which was charged with promoting Finnish culture. Sukselainen introduced the population question at a board meeting on 11 November 1940. In his opinion, "promoting Finnishness includes safeguarding the healthy development of our population". In response to his recommendation that the association hold an event to discuss the population question, a meeting was assembled within the week, during which Sukselainen's message was well received. According to his own recollections of the evening, those present agreed that the association would hold a summit on the matter and invite the members of the Population Committee at the Ministry for Social Affairs and Health as well as representatives from organizations whose work related to population issues. The summit was held on 9 December 1940. The opening address was given by the association's chairman, Professor V.A. Heiskanen, and Sukselainen moderated the discussion. His statements included among other things the following: "When low-income people are no longer raising enough children to compensate for our wealthier folk, we must thoroughly re-evaluate the situation, create circumstances in which every citizen fulfills his or her duty and ensure that society is doing everything 
it can to address the problems that complicate the lives of large families. To effect such change, we need a strong education campaign and courageous social reform. Education can only be undertaken through voluntary efforts. For that reason, all of the citizens and organizations interested in population policy issues must collaborate. We can greatly reduce child mortality by improving child care, finding guardians and care-takers for war orphans, providing support and security for child evacuees and for the large families now living in poverty along our eastern border. And finally, we must make it easier for people to set up a home and we must improve overall living conditions".

Sukselainen proposed the establishment of an institution to represent all parties involved in population policy, which would be charged with the creation of a population policy program, the dissemination of accurate information regarding population policy, and awareness-raising. Participants agreed that a single, unifying body was needed to handle population issues, and a ten-member committee was selected to begin preparations. V.J. Sukselainen was nominated the convener of the committee.

The committee set to work vigorously and held its first meeting on 18 December 1940. V.J. Sukselainen became committee chairman. That first meeting addressed the planning of the central body's activities and a decision was reached to propose cooperation with the Population Committee of the Ministry for Social Affairs and Health. Around Christmas-time, the committee finalized a draft for the new organization's rules and procedures and approved them at a committee meeting on 8 January 1941. The Ministry for Social Affairs and Health and its Population Committee were positively disposed toward the establishment of a central organization to handle all population questions. The Ministry issued a statement on the draft by-laws and nominated two committee members to the new organization's board. On 30 January 1941 the committee held a preparatory meeting for a founding meeting, and the new organization was given the name 'Väestöliitto' and entered into the Register of Associations.

Väestöliitto's founding meeting was held at the University of Helsinki student union, or "Vanha", on 14 February 1941. The meeting established and approved the articles of association and elected V.J. Sukselainen as chairman. The goals he had planned for the central organization were clearly outlined in the mission statement included in the organization's rules of association: "The goal of the organization is to disseminate information about the significance of the size and quality of the population, both in terms of the size and the material and spiritual progress of our nation's population, and with this in mind, to monitor the development of Finland's population and create conditions in which it can grow and prosper, through educating the public and, when necessary, by promoting needed social reforms". The mission remains in effect almost in full, even though the articles have been amended several times in response to changes 
in the social environment and legislation and new working methods. Twenty national and professional organizations, which together represented an extraordinary level of expertise and political muscle, were brought together to form Väestöliitto.

V.J. Sukselainen took on the population question with vigor. "The Finnish Population Question", a ten-page article penned by him, was published in the first 1941 issue of Suomalainen Suomi (now Kanava). During its initial year Väestöliitto had no employees, but the chairman and other officials received support from the staff of the Association of Finnish Culture and Identity, helping to achieve a relatively good level of publicity as well as the organization of a Mother's Day celebration at the Finnish National Theatre in May 1941, an event that was dignified with the presence of Risto Ryti, President of Finland, and his wife. Minister of Education Antti Kukkonen delivered a greeting from the Finnish government. The Prime Minister, several ministers from the government and numerous members of parliament took part in the celebration, which aimed to highlight the importance of the work of mothers. Through its skillful chairman, Väestöliitto quickly achieved a visible and accepted position in society. In the early stages, V.J. Sukselainen and the organization received enthusiastic and expert support from all of the members of its board, particularly its vice-chairs Elsa Enäjärvi-Haavio, Ph.D., and Professor Aarno Turunen, as well as Heikki von Hertzen, Master of Laws. In 1943, von Hertzen became Väestöliitto's first executive director.

Under Sukselainen's leadership, the board devised a wide-reaching program of social reform that no political party would have been able to implement alone. The board's membership came from a number of political organizations and was complemented by two representatives from the Ministry of Social Affairs and Health. This ensured the flow of information and exchange of ideas not only within the board itself but also with the government and the political parties. Significantly, this made it possible to prioritize the many necessary initiatives called for in the reconstruction of post-war Finland. In his capacity as secretary to the prime minister in 1941-45, chairman of the board, Member of Parliament, and former minister of several ministries, Sukselainen took advantage of the opportunities that these positions afforded him to improve the situation of families with children and promote Väestöliitto's program.

Martta Salmela-Järvinen, a Social Democrat and member of parliament, joined the board in 1942 and was elected Vice Chair in 1951. With more than two decades of experience she noted in 1966 that collaboration within Väestöliitto was relaxed and frictionless. I had a similar impression when I worked with Sukselainen for years, as executive director of Väestöliitto and as member of the board at the Alli Paasikivi Foundation. As an individual, Sukselainen, or 'VJ', as those who knew him called him, was calm and easygoing, but firm whenever the situation called for it. He was very good at rallying 
people to work toward common goals, and gave a lot of freedom to those he trusted to be proactive and take action. It was characteristic of him to rely on knowledge, strive to understand existing facts, and take advantage of opportunities as they arose.

In a 60th anniversary publication on V.J. Sukselainen, Atte Pakkanen, who was a member of Väestöliitto's board and also of parliament, gave an excellent example of Sukselainen's working methods. During World War II, Sukselainen worked as secretary to Prime Minister J.W. Rangel. Part of his job was opening up the prime minister's mail. In one letter, a soldier at the front, with a large family, had written about the overwhelmingly difficult financial situation that the family found itself in, of the daily struggle for survival which he himself was helpless to improve. Before presenting the letter to the prime minister, Sukselainen forwarded a copy to Juuso Walden, then Minister of Defense, who was very powerful in the war-time government. Walden warmed to the issue. Sukselainen presented the matter to the Finnish Government, which passed a declaration of principle to the effect that 50 million Finnish marks would be allocated to help low-income families with children. Sukselainen inserted the plan into the prime minister's New Year's speech, and on New Year's Day 1943, the plan was announced to the nation.

V.J. Sukselainen was quite knowledgeable about taxation. Under his guidance, Väestöliitto succeeded in the first few years of its existence in reducing the tax burden on families with children through both national and local tax breaks. His study "Family Considerations in Income and Property Taxation" (222 pp.) came out in 1946. It was an extensive report on different forms of taxation and their impact on individuals and families. Sukselainen's study also proposed a model of taxing per consumption unit. In his conclusion Sukselainen noted that taxing families fairly is comparable to the leveling of costs in relation to families, an issue that is principally a population policy issue.

Sukselainen's study on leveling the costs to families appeared in 1950 as "Leveling the Cost of Parenthood" (210 pp.). The publication was fundamentally a population policy analysis. The idea of leveling the costs related to building a family is based on the idea that in an agrarian society and subsistence economy, rearing children represents a capital investment (as future labor) in a business sense. In today's society, however, children can no longer be likened to the accrual of capital, except in terms of the national economy. Therefore, society must participate in the costs that result from having a family - in other words, to help level the burden among all citizens. We should note here that in 1948, Sukselainen chaired a committee appointed by the government that was charged with laying the groundwork for the child benefit system. The General Child Benefit Act was passed in parliament almost to the letter of the committee's proposal and was enacted into law on 1 October 1948. All children under 
16 were now eligible for the child benefit. To date, the child benefit legislation is the most crucial family policy benefit in Finland.

Each of the above studies was published in Väestöliitto's Population Research Institute series. From the start, because Väestöliitto was assigned the task of monitoring population development in Finland and preparing reports for needed reforms, a population policy research institute (now called the Population Research Institute) was established in 1946 to implement these tasks. V.J. Sukselainen was appointed as head of the Institute. Over the years, the Institute became an important department within Väestöliitto. It conducted independent research and published reports on population issues, and functioned as a vital source of information whenever Väestöliitto prepared socio-political reform initiatives. The Institute also helped diversify the organization's international network in family and population research.

Since its founding, Väestöliitto's board of directors has also discussed the housing question. As early as the fall of 1942, a committee set up by the organization and chaired by V.J. Sukselainen was assigned the task of advocating for families with children in the construction of housing in post-war Finland. Heikki von Hertzen's book "A Home or the Barracks for Our Children?" (Koti vai kasarmi lapsillemme") was published in 1946. The book was a wake-up call on behalf of more effective housing construction policies. The country engaged in a lively debate on the housing question. Migration from rural to urban areas increased, contributing further to the need for more housing. The 400,000 refugees from the area lost in the war had to be housed, and the population centers in Lapland destroyed during the war had to be rebuilt. Housing production required both practical resources and useful examples. As executive director, von Hertzen proposed the construction of a garden city and prevailed on Chairman V.J. Sukselainen and the board to approve the initiative. The organization took out a loan to purchase 238 hectares of land approximately 10 kilometers to the west of Helsinki for future urban construction. Under Sukselainen, Väestöliitto took on many calculated risks, of which the garden city was a courageous example. The organization founded The Housing Foundation of Finland to plan the development and recruited four other influential organizations to collaborate on the project. V.J. Sukselainen was elected chairman of the foundation's delegation. The garden city of Tapiola, which has received international acclaim, is the crowning accomplishment of the Housing Foundation. Today, the Housing Foundation advocates on behalf of high-quality housing and living environments.

While compiling data for his dissertation, V.J. Sukselainen had traveled widely in Europe, gaining an understanding of the value of sharing experiences with others. Therefore, from the very beginning, Väestöliitto has worked to make connections with family organizations in other countries. It has shared information with represen- 
tatives from the Swedish "Friends of the Family" Society (Riksförbundet Svenska Familjevänner) regarding family and population policy issues since 1942. After the war, V.J. Sukselainen as the federation's president and Heikki von Hertzen as its executive director took part in the first international family conference in Paris in 1947 and were simultaneously part of forming the International Union of Family Organizations (IUFO), today known as the World Family Organization. Through its representatives, the federation was active in the organization, and later also in many other international family and population organizations, such as IPPF, COFACE, IUSSP and EAPS. V.J. Sukselainen steered Väestöliitto's staff to establish international contacts and encouraged them to learn foreign languages. During his term as chairman, Sukselainen required anyone traveling to an international conference or meeting to write a report on the trip and distribute it to the board and any other interested parties - a tradition that lives on to this day.

In September 1944, the war between Finland and the Soviet Union came to an end. In accordance with the interim peace treaty signed by both countries, the government was compelled to disband the Lotta Svärd organization on 23 November 1944. Lotta Svärd had provided support to the Finnish Civil Guard Organization, for example by protecting religion, home and the country, and had helped to defend Finland. During the war, the organization had worked at the front feeding soldiers and providing medical care with great success and similar sacrifices. The organization's members consisted of approximately 242,000 women and 50,000 girls. When the organization's operations were ceased, many were eager to take advantage of the property that became available, and many politically motivated debates on the matter ensued for many years in parliament and the media.

During his time as Minister of the Interior V.J. Sukselainen had noticed that no use had been found yet for the Lotta Svärd Organization's property, which was not owned by the state. On his initiative, Sukselainen and Leo Kaprio, L.M., and the Honorable Yrjö Laine established a foundation on 20 September 1952 to which Alli Paasikivi, wife of the President of Finland, lent her name and offered her support by serving as honorary chair. The Alli Paasikivi Foundation was thus founded. The foundation's start-up capital came from a 100,000 mark donation from Väestöliitto. The government transferred Lotta Svärd's resources - approximately 75 million marks - to the foundation. In a meeting on 9 January 1953 the board of Väestöliitto approved the actions of Sukselainen and other parties who were close to the organization as, in accordance with its own by-laws, the foundation had to use the funds for purposes that were similar to those for which Väestöliitto worked. The Foundation's bylaws of association are amended to the minutes of the meeting of Väestöliitto's board. Katri Laine, Ph.D. (1952-1959) was appointed the foundation's first chair, and Sukselainen, who was on its board from the outset, chaired the foundation from 1960 
until 1992. The foundation awarded its first grants in 1953. To date, the foundation has given out approximately 700 grants.

The Alli Paasikivi Foundation works to improve the social safety of families and dispenses grants for research, projects and education initiatives dealing with population, family, housing policies and managing the quality of life of young people and the elderly. The foundation is Finland's foremost proponent of population research.

After he stepped down as chair of Väestöliitto and the Alli Paasikivi Foundation, both organizations invited V.J. Sukselainen to continue as honorary chair.

During his long chairmanship, V. J. Sukselainen created an operational culture within Väestöliitto that was characterized by reform-mindedness and a willingness to take risks. He also encouraged close cooperation with the government and parliament. The organization has been able to use its own research and reports when addressing issues with which it is concerned. After the war, when others busied themselves with Nordic cooperation, Väestöliitto immediately looked to Europe to form contacts with research institutions and organizations concerned with family and population issues. The federation internationalized quickly, serving as an excellent foundation for carrying out its endeavors. 